\title{
Keanekaragaman Jenis Amfibi untuk Mendukung Kegiatan Ekowisata di Desa Braja Harjosari Kabupaten Lampung Timur
}

\author{
Angga Arista ${ }^{1}$, Gunardi Djoko Winarno ${ }^{1}$, Rudi Hilmanto ${ }^{1}$ \\ ${ }^{1}$ Fakultas Pertanian, Universitas Lampung \\ Email: anggaarista76@gmail.com
}

\begin{abstract}
Amphibian life in nature is an interesting case which can be an ecotourism interest. The life cycle as well as the uniqe behaviours of the amphibi, is an interesting case to support the ecotourism activities. This research intends to determine the richness of amphibian minds, the diversity of amphibian kinds, and the amphibian distribution in order to support the ecotourism activities and to determine the society perception in utilizing the amphibi for the ecotourism activities. A combination of line transect method and Visual Encounter Survey method were used to know the species richness diversity and the distribution. One score one indicator quisioner was used to know the society perception against the amphibi to support ecotourism. The research was conducted in Braja Harjasari Village, East Lampung Regency during March to April 2017. Data analyzing was used a Shannon-wiener and Margalef index. The sosciety perception was analyzed descriptively and showed in a chart. The result showed that the amphibian richness was 0,6 which mean low, the diversity was 1,0 which meant medium, the shannon-wiener and margalef index was 0,9 which mean low community was stable and each kind of the amphibi was distributed equally. The society perception against the amphibi to support the ecotourism activities was mostly positive.
\end{abstract}

Key words : amphibi, diversity, ecotourism, society perception

\begin{abstract}
Abstrak
Kehidupan amfibi di alam merupakan suatu hal yang menarik untuk dijadikan daya tarik ekowisata. Siklus hidup maupun perilaku amfibi yang unik, merupakan suatu hal yang menarik untuk mendukung kegiatan ekowisata. Tujuan penelitian untuk mengetahui kekayaan jenis, mengetahui keanekaragaman jenis amfibi, mengetahui penyebaran amfibi dalam mendukung kegiatan ekowisata dan mengetahui persepsi masyarakat dalam pemanfaatan amfibi untuk kegiatan ekowisata. Metode yang digunakan untuk mengetahui keanekaragaman kekayaan dan kemerataan amfibi yaitu kombinasi antara line transect dan Visual Encounter Survey. Metode untuk mengetahui persepsi masyarakat terhadap amfibi untuk mendukung ekowisata digunakan kuisioner one skor one indicator. Penelitian dilaksanakan di Desa Braja Harjasari Kabupaten Lampung Timur selama bulan Maret sampai April 2017. Analisis data menggunakan indeks shannon-wiener dan margalef. Analisis persepsi dianalisis secara deskripstif dan disajikan dalam grafik. Hasil penelitian menunjukan kekayaan jenis amfibi sebesar 0,6 yang berarti rendah, keanekaragaman sebesar 1,0 yang berarti sedang, indeks kemerataannya sebesar 0,9 yang berarti komunitas stabil dan tiap jenis tersebar secara merata. Persepsi masyarakat mengenai amfibi untuk mendukung kegiatan ekowisata cenderung positif.
\end{abstract}

Kata kunci: Amfibi, ekowisata, keanekaragaman, persepsi masyarakat

\section{Pendahuluan}

Stebbins \& Cohen (1997) berpendapat bahwa herpetofauana (amfibi dan reptil) memiliki peran sangat penting bagi penyusunan suatu ekosistem, secara ekologis herpetofauna berperan sebagai pemangsa konsumen primer seperti serangga atau hewan invertebrata lainnya. Secara ekonomis, beberapa jenis herpetofauan dapat dijadikan sumber protein hewani, hewan peliharaan, dan bahan obat-obatan. Kehidupan amfibi di alam merupakan suatu hal yang menarik untuk dijadikan daya tarik ekowisata. Berbagai aktivitas satwa liar menjadi hal yang unik untuk disajikan kepada wisatawan dalam kemasan ekowisata.

Pemukiman yang berbatasan langsung dengan TNWK (Taman Nasional Way Kambas) ini memiliki banyak potensi yang dapat dikembangkan melalui pengembangan wisata desa. Bersama dengan pihak taman nasional, masyarakat di sekitar kawasan hutan menjadi sumber daya pendukung utama dalam kegiatan ekowisata satwa liar (Haidawati dkk., 2016). Atraksi satwa liar yang dapat diamati langsung dari pemukiman tersebut, merupakan salah satu objek wisata yang menarik untuk dikemas menjadi ekowisata.

Penelitian ini bertujuan untuk mengetahui kekayaan jenis, keanekaragaman jenis, dan mengetahui penyebaran amfibi dalam mendukung kegiatan ekowisata, serta mengetahui persepsi masyarakat dalam pemanfaatan amfibi untuk kegiatan ekowisata di Desa Braja Harjosari.

\section{Metode Penelitian}

Penelitian ini dilakukan selama bulan Maret sampai April 2017, di Desa Braja Harjosari Kabupaten Lampung Timur. Alat dan bahan yang digunakan berupa jam digital, tongkat kayu, karet jepang, binokuler, kamera, GPS, serta alat tulis dan tally sheet. Bahan yang digunakan adalah spesies amfibi yang teramati. 
Data sekunder merupakan data penunjang yang berkaitan dengan penelitian ini untuk mencari, mengumpulkan, dan menganalisis data menggunakan studi liter atur.

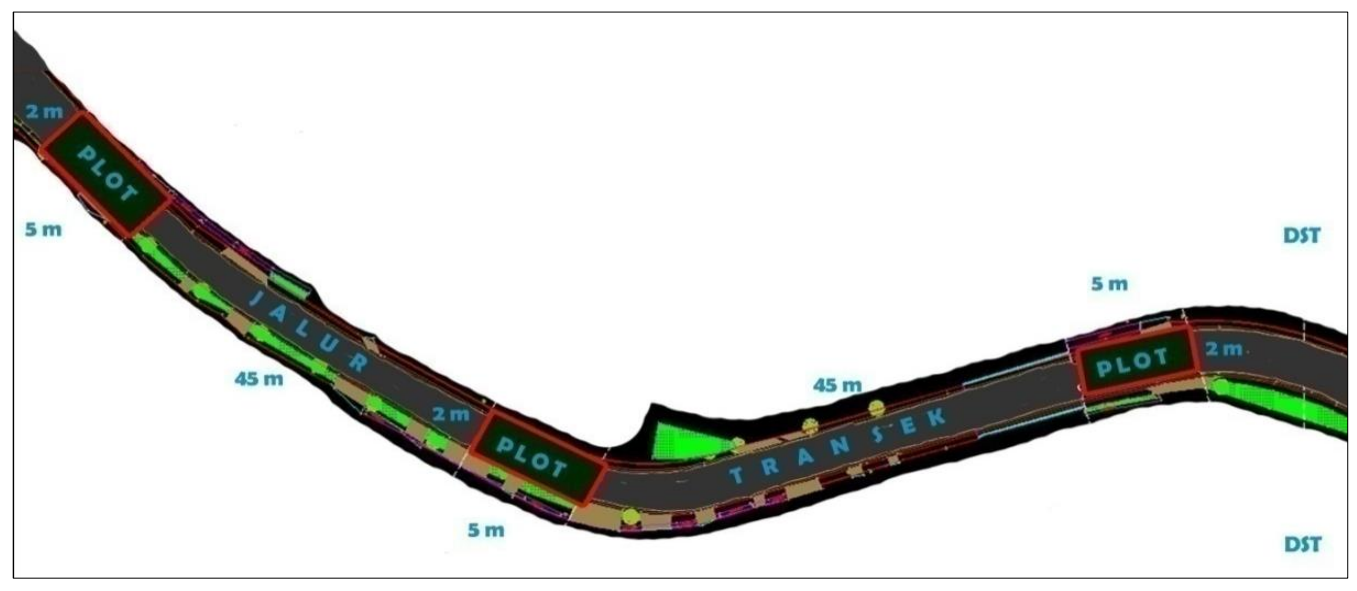

Gambar 1. Sketsa Tekhnik Pengambilan Data Amfibi di Sepanjang Jalur Transek

\section{Orientasi Lapangan}

Orientasi lapangan dilakukan sebelum pengamatan, ini bertujuan untuk mengenal areal penelitian, kondisi lapangan, dan titik pengamatan untuk memudahkan pengamatan.

\section{Kombinasi Metode Line Transect dan Visual Encounter Survey.}

Pengamatan amfibi menggunakan metode kombinasi line transek dan Visual Encounter Survey. Line Transek adalah jalur sempit melintang lokasi yang akan diamati (Ramazas, 2012). Metode Visual Encounter Survey menggunakan plot yang dibuat untuk mengamati satwa liar dan menentukan kekayaan jenis suatu daerah, untuk menyusun suatu daftar jenis, serta untuk memperhatikan kelimpahan jenis-jenis relatif yang ditemukan (Heyer dkk., 1994).

\section{Metode Kuisioner}

Kuisioner merupakan tekhnik pengumpulan data yang dilakukan dengan cara memberikan seperangkat pertanyaan atau pernyataan tertulis kepada responden untuk kemudian dijawab (Sugiyono, 2013). Jumlah responden sebanyak 30 responden, ukuran sampel paling minimum analisis data statistik adalah 30 responden (Mahmud, 2011).

\section{Analisis Data}

Panduan jenis-jenis amfibi diambil berdasarkan buku panduan lapang keanekaragaman jenis herpetofauna. Guna mengetahui keanekaragaman jenis amfibi dihitung dengan menggunakan indeks keanekaragaman Shannon-Wienner (Odum, 1993; Indriyanto 2006), dengan rumus sebagai berikut.
Rumus :

$H^{\prime}=-\sum P i \ln (P i), \operatorname{dimana} P i=(n i / N)$

Digunakan untuk mengetahui nilai indeks kekayaan jenis dihitung menggunakan rumus Margalef sebagai berikut.

$\mathrm{Dmg}=\frac{s-1}{\ln N}$

Digunakan untuk mengetahui nilai indeks kemerataan mengunakan rumus sebagai berikut.

$\mathrm{J}=\frac{H^{\prime}}{\ln S}$

Digunakan untuk mengetahui pola sebaran spasial, dicari persamaan sebagai berikut.

$X=\frac{\sum x i . f i}{\sum f i} \operatorname{dan} \mathrm{S}^{2}=\frac{\sum\left(x i^{2} \cdot f i\right)-x . n}{N-1}$

\section{Analisis Peresepsi}

Analisis persepsi diuraikan dalam bentuk kalimat. Rata-rata nilai persepsi terhadap masyarakat mengenai persepsi positif dan negatif terhadap amfibi, amfibi dalam kegiatan ekowisata serta dampak positif dan negatif ekowisata. Kesenjangan dianalisis berdasarkan kumulatif nilai persepsi.

\section{Hasil Dan Pembahasan}

Hasil pengamatan yang dilakukan di Desa Braja Harjosari terdapat tiga jenis amfibi, terdiri dari dua Famili (Famili Ranidae dan Famili Bufonidae) yang berasal dari Ordo Anura. Jumlah individu yang teramati sebanyak 93 individu selama empat kali pengulangan pengamatan.

Jenis-jenis amfibi yang ditemukan selama pengamatan dapat dilihat pada Tabel 1 , disertai Ordo dan Familinya. 
Tabel 1. Jenis-Jenis Amfibi Yang Berhasil Diidentifikasi Pada Lokasi Pengamatan.

\begin{tabular}{lllllll}
\hline No & Ordo & Famili & Jenis & Nama Lokal & $\overline{\mathbf{x}}$ & Max \\
\hline 1 & Anura & Ranidae & Huia Masonii & Kongkang Jeram & 10 & 12 \\
& & & Fejervarya cancrivora & Kodok Sawah & 8 & 9 \\
& & Bufonidae & Bufo biporcartus & Kodok Puru & 5 & 5 \\
\hline$\Sigma$ & 1 & 2 & 3 & & 23 & 26 \\
\hline
\end{tabular}
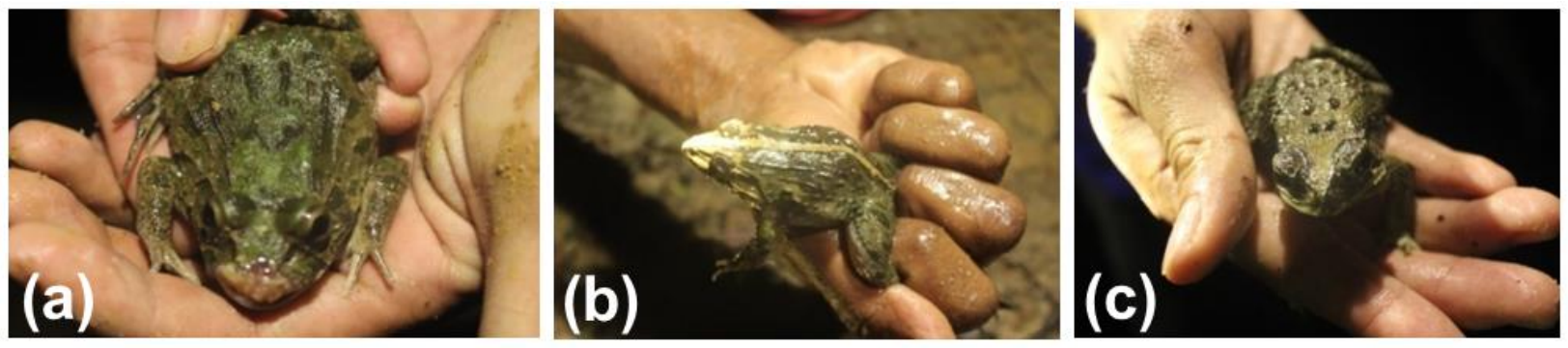

Gambar 2. (a) Huia Masonii, (b) Fejervarya cancrivora dan (c) Bufo biporcartus

\section{Tabulasi Hasil Perhitungan}

Tabulasi hasil perhitungan yang teridentifikasi pada lokasi pengamatan di Desa
Braja Harjosari Kabupaten Lampung Timur dapat dilihat pada Tabel 2.

Tabel 2. Indeks Keanekaragaman, Kekayaan Jenis dan Kemerataan Jenis Amfibi

\begin{tabular}{ccccc}
\hline \multirow{2}{*}{ No } & \multirow{2}{*}{ Jumlah Individu } & \multicolumn{3}{c}{ Nilai Indeks } \\
\cline { 3 - 5 } & & Keanekaragaman & Kekayaan & Kemerataan \\
\hline 1 & 93 & 1,0 & 0,6 & 0,9 \\
\hline
\end{tabular}

\section{Keanekaragaman Jenis Amfibi}

Indeks keanekaragaman sebesar 1,0 yang berarti keanekaragamnnya sedang, berbeda dengan penelitian yang telah dilakukan sebelumnya. Pada habitat yang berbeda mendapatkan indeks keanekaragaman yang berbeda pula. Habitat hutan sebesar 1,8, habitat perkebunan sebesar 1,5 dan habitat sungai sebesar 1,3 (Ariza dkk., 2014) pada jalur habitat akuatik sebesar 0,9 , pada habitat terestrial dengan nilai keanekaragaman 0,7 (Yani dkk., 2015). Nilai indeks keanekaragaman jenis amfibi dan reptil di gumuk pasir sepanjang pesisir selatan Provinsi Daerah Istimewa (DI) Yogyakarta relatif rendah, karena kondisi lingkungan yang ekstrim sehingga hanya jenis tertentu yang dapat toleransi dan beradaptasi hidup (Qurniawan et al., 2013).

Aktivitas manusia merupakan salah satu faktor yang dapat membedakan angka keanekaragaman yang didapat (Yudha dkk., 2013), selain itu vegetasi yang terdapat pada lokasi pengamatan juga merupakan faktor penentu. Lokasi penelitian yang terbuka mempermudah predator untuk memangsa amfibi, mengingat bahwa predator adalah salah satu faktor biotik yang mempengaruhi keanekaragaman (Izza, dkk., 2014).

Habitat (Yudha dkk., 2015) dan luas areal penelitian juga menentukan nilai indeks keanekaragaman (Sari, 2014). Menurut Rahayuningsih dkk. (2012) bahwa satwa liar akan semakin beranekaragam bila struktur habitatnya juga beragam. Pada lokasi pengamatan tipe habitatnya sejenis, yaitu berupa anak sungai. Tipe habitat yang sejenis mengakibatkan hanya jenis-jenis tersebut saja yang dapat hidup pada lokasi pengamatan, karena sumber pakan yang tersedia tidak beragam.

\section{Kekayaan Jenis Amfibi}

Nilai indeks kekayaan jenisnya sebesar 0,6 yang berarti kekayaannya rendah. Tidak adanya vegetasi pohon yang tumbuh menjadi salah satu faktor penentu. Struktur vegetasi hutan merupakan salah satu bentuk pelindung dan sumber pakan, kurangnya sumber pakan menyebabkan satwa berpindah (Findua, 2016).

\section{Kemerataan Jenis Amfibi}

Nilai indeks kemerataan spesies dapat menggambarkan kestabilan suatu komunitas. Pada lokasi pengamatan nilai indeksnya 0,9, 
berarti komunitas stabil. Hal tersebut menunjukan bahwa tidak ada dominansi satu spesies yang memiliki jumlah individu lebih banyak dibandingkan individu lainnya (Sardi, 2014).

\section{Pola Persebaran Amfibi}

Pola persebaran bagi satwaliar merupakan strategi untuk mempertahankan kelangsungan hidupnya. Pola persebaran suatu jenis satwa dapat berbentuk acak, homogen/merata atau mengelompok. Berdasarkan hasil analisis, secara umum pola sebarannya adalah berbentuk homogen/merata. Hal ini berarti ketersediaan pakan, pohon pelindung, dan sumber air di lokasi penelitian tersebar secara merata (tidak terfokus pada suatu wilayah).

\section{Tingkat Kesenjangan Persepsi terhadap Amfibi}

Persepsi masyarakat mengenai amfibi memiliki kesenjangan antara persepsi positif dan negatif. Kesenjangan persepsi terhadap amfibi memiliki nilai positif. Dari kriteria-kriteria yang diberikan $69 \%$ jawaban masyarakat lebih dominan setuju dengan persepsi positif.

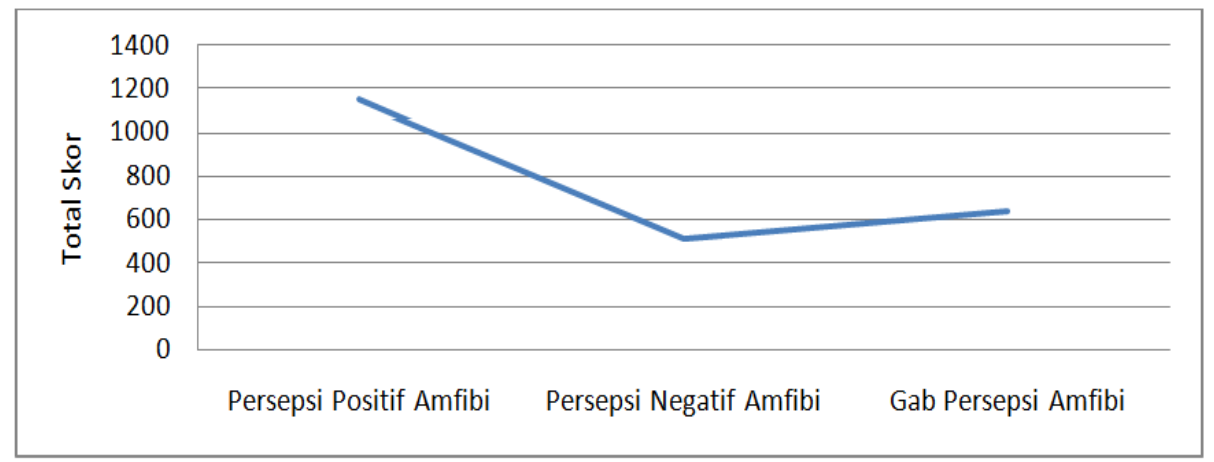

Gambar 3. Grafik kesenjangan persepsi masyarakat terhadap amfibi.

Amfibi yang terdapat di Desa Braja Harjosari tidak memiliki ancaman besar, karena masyarakat mulai menyadari pentingnya amfibi. Bukan berarti amfibi di desa tersebut tidak terdapat ancaman sama sekali, masih ada beberapa masyarakat yang memburu amfibi untuk memenuhi kebutuhan ekonomi maupun kebutuhan protein hewani. Pelestarian yang dilakukan masyarakat desa tersebut masih sebatas mengurangi perburuan, belum ada upaya lain.

\section{Tingkat Kesenjangan Persepsi terhadap Dampak Ekowisata}

Kegiatan ekowisata dapat diterima dengan baik oleh masyarakat Desa Braja Harjosari, hal tersebut terlihat dari kesenjangan antara dampak positif dan negatif dari kegiatan ekowisata. Masyarakat cenderung dominan setuju bahwa ekowisata memberikan keuntungan bagi masyarakat, yaitu sebesar $78 \%$.

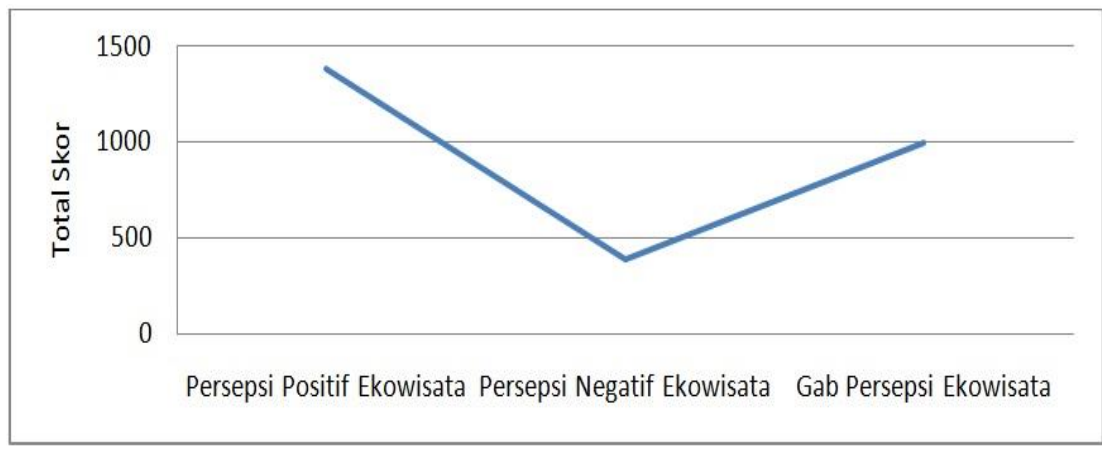

Gambar 4. Grafik perbedaan nilai (kesenjangan) positif negatif dampak ekowisata.

Kegiatan ekowisata dapat berjalan dengan lancar di desa tersebut. Namun fasilitas-fasilitas yang ada harus terus diperbaiki untuk kenyamanan wisatawan. Seperti jalan yang kurang baik harus segera dibenahi, fasilitas kesehatan seperti puskesmas harus mudah dijangkau, tempat pembuangan sampah harus ditempatkan pada titik yang menyebar, serta fasilitas-fasilitas lainnya. Masyarakat dapat berpartisipasi dalam bentuk buah pikiran, tenaga, harta benda, kemahiran dan keterampilan serta partisipasi sosial (Rosida, 2014), salah satu 
bentuk partisipasi masyarakat Desa Braja Harjosari dengan membentuk POKDARWIS (Kelompok Sadar Wisata).

Daya tarik wisata dapat dijaga dengan cara menjaga lingkungan agar tetap alami dan menjaga keaslian budaya lokal (Imran, 2012), hal tersebut telah diterapkan masyarakat Desa Braja Harjosari. Terbukti dengan lestarinya tarian daerah serta kehidupan berjalan secara tradisional. Masyarakat membutuhkan skill/keahlian, keterampilan, manajemen dan pengetahuan tentang perilaku, kebutuhan dan keinginan para wisatawan (Priono, 2012), hal tersebut yang mendorong masyarakat memperbaiki kemampuan Bahasa Inggris agar mempermudah komunikasi kepada wisatwan asing. Ekowisata meningkatkan ekonomi masyarakat yang nantinya akan terwujud suatu kehidupan yang serasi, seimbang, dan selaras dengan lingkungan (Muhlisin, 2013).

\section{Persepsi Masyarakat Terhadap Amfibi Dalam Kegiatan Ekowisata}

Masyarakat dapat menerima bahwa amfibi dapat mendukung kegiatan ekowisata di desa tersebut. Rata-rata masyarakat agak setuju (skor 5) pada kriteria yang diberikan. Belum terealisasinya kegiatan pemanfaatan amfibi untuk mendukung kegiatan ekowisata, menjadi faktor yang membuat masyarakat belum setuju sepenuhnya. Masyarakat belum merasakan manfaatnya langsung. Namun demikian, masyarakat percaya apabila direalisasikan dengan baik maka pemanfaatan amfibi untuk mendukung kegiatan ekowisata akan berdampak baik bagi kegiatan wisata yang ada.

Data mengenai amfibi di Indonesia masih sangat minim, hal tersebut membuat masyarakat setuju apabila informasi mengenai amfibi akan menjadi hal yang menarik bagi wisatawan. Wisatawan akan mendapat pengetahuan baru mengenai amfibi, dengan demikian amfibi dapat dijadikan objek wisata bahkan ikon bagi Desa Braja Harjosari. Siklus hidup amfibi merupakan metamorfosis sempurna, hal tersebut dapat dijdikan sarana edukasi bagi wisatawan.

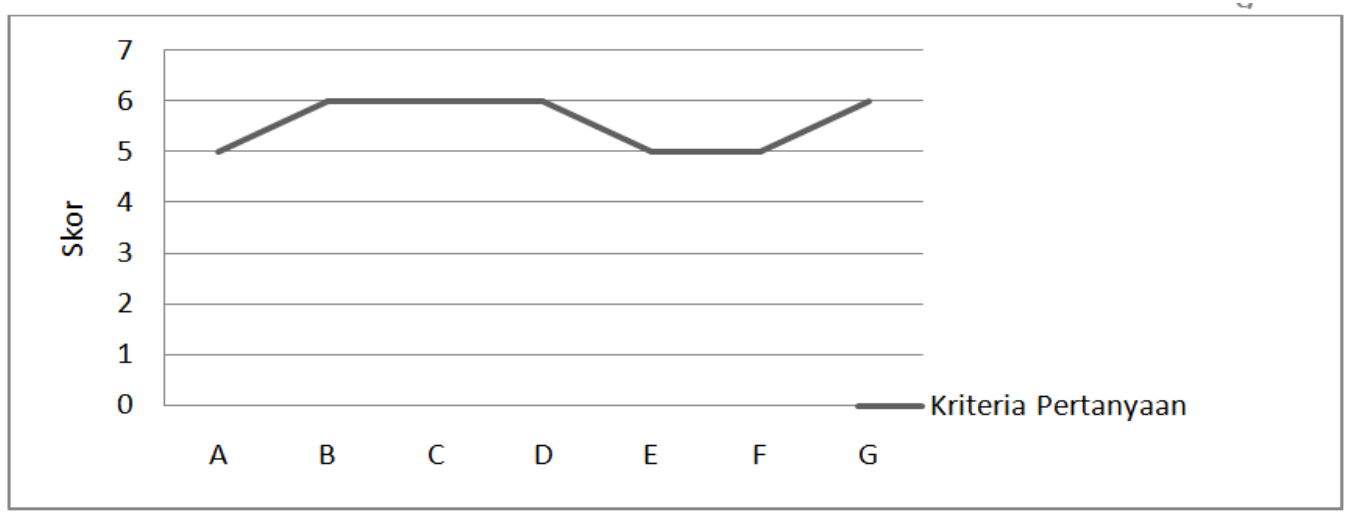

Keterangan:

Gambar 5. Persepsi masyarakat terhadap amfibi dalam kegiatan ekowisata

Skor: 1. Sangat tidak setuju 2. Tidak setuju 3. Agak tidak setuju 4. Biasa saja 5. Agak setuju 6. Setuju 7. Sangat setuju

Kriteria Pertanyaan

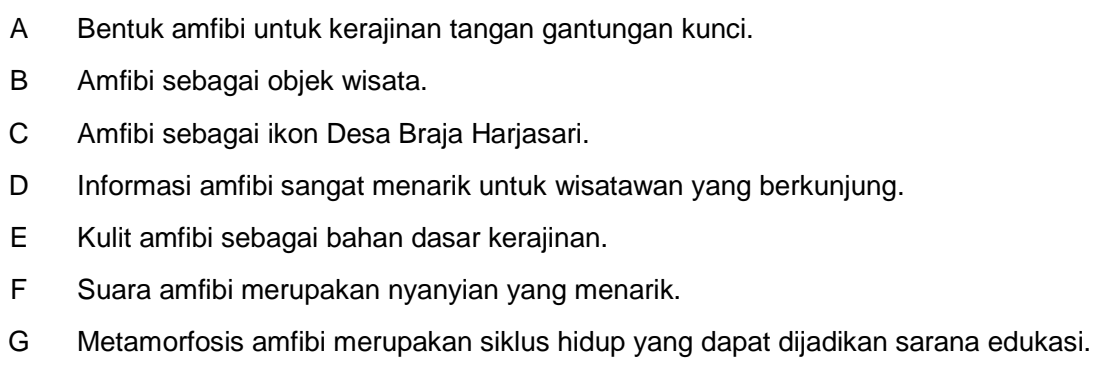

Bentuk amfibi yang unik menjadikannya salah satu tokoh kartun yaitu Keropi, hal tersebut menjadikan peluang bentuk amfibi untuk dijadikan kerajinan tangan yang dapat dijadikan cindera mata atau oleh-oleh bagi wisatawan. Kerajinan tangan berbentuk amfibi dapat berupa gantungan kunci, boneka, patung ataupun lainnya. Musim kawin pada awal-awal musim hujan (Syazali dkk., 2016), beberapa jenis amfibi kerap membentuk "grup nyanyi". Beberapa jantan berkumpul dan 
bersahut-sahutan. Suara tersebut terdengar lantang dan jelas, suara yang terdengar teratur akan membuat seolah-olah sebuah nyanyian yang menarik untuk didengar.

\section{Simpulan}

Hasil penelitian menunjukan kekayaan jenis amfibi sebesar 0,6 yang berarti rendah, terdapat tiga jenis amfibi yaitu Huia Masonii, Fejervarya cancrivora dan Bufo biporcartus, terdiri dari dua Famili (Famili Ranidae dan Famili Bufonidae) yang berasal dari Ordo Anura. Keanekaragaman sebesar 1,0 yang berarti sedang, keanekaragamannya dipengaruhi oleh faktor habitat yang sejenis, aktivitas manusia serta

\section{Daftar Referensi}

Ariza, Y. S., Dewi, B. S., dan Darmawan, A. 2014.Keanekaragaman Jenis Amfibi (Ordo Anura) Pada Beberapa Tipe Habitat Di Youth Camp Desa Hurun Kecamatan Padang Cermin Kabupaten Pesawaran. Jurnal Sylva Lestari. Vol 2. No. 2:21-30.

Findua, A. W., Harianto, S. P., dan Nurcahyani, N. 2016. Keanekaragaman Reptil Di Repong Damar Pekon Pahmungan Pesisir Barat (Studi Kasus Plot Permanen Universitas Lampung). Jurnal Sylva Lestari. Vol 4. No $1: 51-60$

Haidawati, Rustiati, E.L., Kanedi, M., dan Priyambodo. 2016. Agrowisata Kebun Jambu Kristal Sebagai Potensi Ekonomi Alternatif Desa Penyangga Taman Nasional Way Kambas Lampung Timur. Universitas Lampung. Bandar Lampung.

Heyer, W. R., Donnelly, M. A., Diarmid, M. C.,Hayek, L. C., dan Foster MS. 1994. Measuring and Monitoring Biological Diversity: Standard Methods for Amphibians. Washington: Smithsonian Institution Press.

Imran, A. N. 2012. Identifikasi Kapasitas Komunitas Lokal Dalam Pemanfaatan Potensi Ekowisata Bagi Pengembangan Ekowisata Di Kawah Cibuni. Jurnal Perencanaan Wilayah dan Kota. Vol. 23 No. 2:85-102.

Indriyanto. 2006. Ekologi Hutan. Jakarta: Penerbit PT Bumi Aksara. Izza, Q., Kurniawan, N. 2014. Eksplorasi Jenis Jenis Amfibi di Kawasan OWA Cangar dan Air Terjun Watu Ondo, Gunung Welirang, TAHURA R.Soerjo. Jurnal Biotropika. Vol 2. No. 2:103-108.

Mahmud. 2011. Metode Penelitian Pendidikan. Bandung: Pustaka Setia. Muhlisin, A. 2013. lokasi pengamatan yang terbuka mempermudah predator amfibi untuk memburu mangsanya. Indeks kemerataannya sebesar 0,9 yang berarti komunitas stabil dan tiap jenis tersebar secara merata, persepsi masyarakat mengenai amfibi untuk mendukung kegiatan ekowisata cenderung positif, masyarakat setuju bahwa amfibi memiliki karakteristik dan keunikan untuk dikembangkan menjadi faktor pendukung kegiatan ekowisata.

\section{Ucapan Terimakasih}

Penulis mengucapakan terimakasih kepada Kelompok Sadar Wisata Braja Harjosari yang telah membantu dalam penelitian ini.

Ekowisata Sebagai Penunjang Pembelajaran Kontekstual Menumbuhkan Sikap Kepedulian Lingkungan. Jurnal Pendidikan Biologi. Vol . 4. No. 2.

Odum, E. P. 1993. Dasar-Dasar Ekologi. Tj. Samigan. [Penerjemah]; Srigandono [Editor]. Terjemahan dari: Fundamental of Ecology. Gajah Mada Press. Yogyakarta.

Priono, Y. 2012. Pengembangan Kawasan Ekowisata Bukit Tangkiling Berbasis Masyarakat. Jurnal Perspektif Arsitektur. Volume 7 No.1:51-67.

Qurniawan T..F., dan Eprilurahman R. 2013. Keragaman Jenis Amfibi Dan Reptil Gumuk Pasir, Propinsi Daerah Istimewa Yogyakarta. Jurnal Zoo Indonesia. Vol 22. No. 2:9-16.

Rahayuningsih, M., Abdullah, M. 2012. Persebaran Dan Keanekaragaman Herpetofauna Dalam Mendukung Konservasi Keanekaragaman Hayati Di Kampus Sekaran Universitas Negeri Semarang. Indonesian Journal of Conservation Vol. 1 No. 1:1-10.

Ramazas. 2012. Ekologi Umum. Edisi Kedua. UGM: Yogyakarta.

Rosida, I. 2014. Partisipasi Pemuda Dalam Pengembangan Kawasan Ekowisata Dan Implikasinya Terhadap Ketahanan Masyarakat Desa (Studi Di Kawasan Ekowisata Gunung Api Purba Nglanggeran, Desa Nglanggeran, Kecamatan Patuk, Kabupaten Gunung Kidul, Provinsi Daerah Istimewa Yogyakarta). Jurnal Ketahanan Nasional. Vol. XX. No. 2:68-77

Sardi, M., Erianto, Siahaan, S. 2014. Keanekaragaman Herpetofauna Di Resort Lekawai Kawasan Taman Nasional Bukit Baka Bukit Raya Kabupaten Sintang 
Kalimantan Barat. Jurnal Hutan Lestari. Vol 2. No. 1:126-133

Sari, I. N., Nurdjali, B., dan Erianto. 2014. Keanekaragaman Jenis Ampibi (Ordo Anura) Dalam Kawasan Hutan Lindung Gunung Ambawang Kecamatan Kubu Kabupaten Kubu Raya. Jurnal Hutan Lestari Vol. 2. No. 1:116-125.

Sugiyono. 2013. Metode Penelitian Pendidikan (Pendekatan Kuantitatif, Kualitatif, dan R\&D). Bandung: Alfabeta.

Stebbins, R.C \& Cohen, N.W. 1997. A Natural History of Amphibians. Princeton University. New Jersey.

Syazali, M., Al Idrus, A., Hadiprayitno, G. 2016. Kekayaan Spesies Amfibi di Pulau Lombok, Indonesia. Proceeding Biology Education Conference (ISSN: 2528-5742), Vol 13(1):730-735.
Yani A., Said S., dan Erianto. 2015. Keanekaragaman Jenis Amfibi Ordo Anura Di Kawasan Hutan Lindung Gunung Semahung Kecamatan Sengah Temila Kabupaten Landak Kalimantan Barat. Jurnal Hutan Lestari. Vol. 3. No. 1.

Yudha, D. S., Eprilurahman, R., Trijoko, Alawi, M. F., Tarekat, A. 2013. Keanekaragaman Jenis Katak dan Kodok (Ordo Anura) di Sepanjang Sungai Opak Propinsi Daerah Istimewa Yogyakarta. Jurnal Biologi Volume 18 No 2. Hal 52-59

Yudha, D. S., Eprilurahman, A., Muhtianda, I. A., Ekarini, D. F., Ningsih, O. C. 2015. Keanekaragaman Spesies Amfibi Dan Reptil Di Kawasan Suaka Marga Satwa Sermo Daerah Istimewa Yogyakarta. Jurnal MIPA. Vol. 38. No. 1:8-13. 